\title{
Multinational enterprises and natural disasters: Challenges and opportunities for IB research
}

\author{
Chang Hoon $\mathrm{Oh}^{1}$ and \\ Jennifer Oetzel ${ }^{2}$ \\ ${ }^{1}$ School of Business, University of Kansas, 1654 \\ Naismith Dr, Lawrence, KS 66045, USA; \\ ${ }^{2}$ Management Department, Kogod School of \\ Business, American University, 4400 \\ Massachusetts Ave., Washington, D.C., \\ NW 20016, USA
}

Correspondence:

J Oetzel, Management Department, Kogod School of Business, American University, 4400 Massachusetts Ave., Washington, D.C., NW 20016, USA

e-mail: oetzelj@american.edu
Even with all our technology and the inventions that make modern life so much easier than it once was, it takes just one big natural disaster to wipe all that away and remind us that, here on Earth, we're still at the mercy of nature. Neil deGrasse Tyson

Received: 18 June 2020

Revised: 20 August 2021

Accepted: 7 September 2021

Online publication date: 8 January 2022

\begin{abstract}
The purpose of this paper is to encourage and to extend research on natural disasters and international business (IB). More specifically, we review the characteristics of natural disasters and the unique challenges they pose to the business environment and examine how they differ from other types of disasters/crises often researched in the IB literature. Next, we investigate the applicability and challenges of core IB theories to the study of natural disasters. By extending new internalization theory (NIT) to overcome challenges of bounded rationality and reliability, we identify effective strategies for managing the threat of natural disasters through establishing multi-sector partnerships and alternative supply chains. Integrating research on the characteristics of natural disasters and the insights from NIT, we propose natural disaster management strategies for multinational enterprises (MNEs) based on varying degrees of geographic scope of natural disasters and MNEs. This paper concludes with proposing new research opportunities for IB scholars in disaster preparedness, cross-organizational collaborations, and supply chain management.
\end{abstract}

Journal of International Business Studies (2022) 53, 231-254.

https://doi.org/ I0.1057/s41267-021-00483-6

Keywords: natural disasters; COVID-19 pandemic; multinational enterprises; internalization theory; multi-sector partnerships; supply chain management; climate change; risk management

\section{INTRODUCTION}

In North America and many parts of Europe, the summer of 2021 may be remembered as a watershed moment when it comes to recognition of the threat posed by natural disasters. From news reports of wildfires in British Columbia and Northwest Ontario, Canada, the Sakha Republic in Russia, Sardinia and the Western Mediterranean, Turkey and the Eastern Mediterranean, Finland, and the western United States, to devastating flooding in Germany, Belgium, China, and Lagos, Nigeria (as a few examples), press reports suggest that people are seeing the threat of disasters in a new way, and as more than isolated events (Berger \& Adam, 2021; CNN, 2021; Kahn, 2021; Taylor, 2021).

The threat of disasters is not new. Yet, the ominous predictions of a 'new normal' by climate scientists (Tharoor, 2021), the threat of 
COVID-19 (also a natural disaster) as of this writing, and a retreat from economic and political cooperation, are making the prospects for an effective response to disasters ever more challenging. With respect to the COVID-19 pandemic, individual countries must not only deal with the spread of the virus within their own borders, but also the spread of more contagious, and potentially more lethal, variants from other countries. Yet, vaccine development and distribution, and the containment of cross-border spread of the virus and its variants, requires international cooperation. Like other types of natural hazards, including the potential for floods, wildfires, storms, and earthquakes, among others, contagious viruses need not result in disasters such as epidemics or pandemics (Oetzel \& Oh, 2014; Oh \& Oetzel, 2011). It is when society is not prepared that naturally occurring hazards are most likely to become disasters (Oetzel $\&$ Oh, 2021).

The triggers of natural disasters include various natural forces caused by geophysical, meteorological, hydrological, climatological, and biological forces, but their fundamental causes include not only those natural forces but also human involvement such as urbanization, industrialization, population growth, over-fishing, and over-farming (Howard-Grenville et al., 2014; Kolk \& Pinkse, 2008; Kreimer, Arnold, \& Carlin, 2003; Rivera et al., 2021). Recognizing the gravity of the threat posed by natural hazards, the United Nations (UN) includes the need to promote socio-economic resilience, reduce social and organizational vulnerability to disasters, and address climate change in the UN Sustainable Development Goals (Nohrstedt et al., 2021; Van Tulder, Rodrigues, Mirza, \& Sexsmith, 2021).

Of particular concern are cases where a disaster in one country can trigger cascading events in others. Cascading disasters occur when an initial disaster sets off a sequence of events that, "result in physical, social or economic disruption" and are, "associated more with the magnitude of vulnerability" than with the specific type of hazard involved (Pescaroli \& Alexander, 2015: 65). A classic example of a cascading disaster that affected MNEs and their global supply chains is the earthquake off the coast of Japan in 2011. One hundred people died because of the earthquake and another 18,000 people were killed after the earthquake triggered a tsunami (Pescaroli \& Alexander, 2015: 63). The tsunami then damaged the Fukushima Daiichi Nuclear Power Plant's reactors leading to the evacuation of 200,000 more people from the area (Pescaroli \& Alexander, 2015: 63). Overall, at least 32 million people in Japan are thought to have been affected by radioactive fallout (Smith, 2015). ${ }^{1}$

Due to these events in Japan, global supply chains, particularly in the auto industry, were almost entirely stalled for 90 days. This greatly disrupted automobile production in Europe, the United States, and elsewhere (Olcott \& Oliver, 2014). Agriculture in the region was devastated by radiation causing shortages in food supply. Utilities were also disrupted and there was an exodus of thousands of workers from the region. These events complicated rescue and recovery efforts and negatively affected long-term economic prospects in the region (Pescaroli \& Alexander, 2015: 65).

To be clear, the natural hazards that we face are not new. Rather, what is different today are: (1) the current and predicted increase in the prevalence and severity of natural hazards, particularly those linked to climate change, (2) the growing potential for cascading disasters, and (3) the need for MNEs to prepare for and manage these challenges. If an era of increased international cooperation gives way to a period of deglobalization, preparing for crises that cross borders may be even more challenging. Given this backdrop, the question motivating our research is: does the threat of natural disasters and the potential for cascading events require a new way of thinking about MNEs' risk management across countries? To explore this question, we begin by explaining the unique characteristics of natural disasters compared to other types of disasters/crises. In particular, the underlying natural forces and their interrelationship with human involvement make natural disasters complex, ambiguous, and difficult or even impossible to predict (Courtney et al., 1997).

To understand better the threat of natural disasters, we then examine whether and how several related international business (IB) theories can explain MNE strategy for managing natural disaster threat as compared to other types of uncertainty in the business environment. Based on the insights from these theories, we focus on and extend new internalization theory (NIT) through the analysis of MNE response to the threat of natural disasters focusing on the notions of bounded rationality and reliability. NIT is known for its validity in analyzing and explaining a wide range of recent IB phenomena focusing on two building blocks; the country business environment and firm capabilities (Narula et al., 2019; Rugman \& Verbeke, 2008). We then 
propose strategies for managing the complex threat of natural disasters given the varying degrees of the geographic scopes of natural disasters and MNE operations. We conclude with recommendations for future research and offer specific questions that merit attention.

\section{CONCEPTUAL BACKGROUND}

\section{Natural Hazards and the Increasing Threat of Natural Disasters}

The degree to which a particular location faces a natural hazard is a function of the impact and frequency of the hazard (i.e., the threat; natural forces), and the vulnerability of society to the threat of that disaster (i.e., the ability of humans to mitigate or exacerbate the threat; human involvement) (Fuchs et al., 2012: 1969; Oetzel \& Oh, 2021). Based on the historical record and scientific analysis, it is possible to estimate whether a particular location is prone to specific types of hazards such as earthquakes, volcanic activities, storms, and wildfires. However, there are high levels of uncertainty around the likelihood, frequency, and intensity of major disasters. Unfortunately, such uncertainties are likely to worsen given the rapid pace of climate change and the resulting impact on natural hazards.

Of course, not all locations face the same types of risk, and the frequency and severity of natural hazards differ across countries. Recognizing this, we illustrate the total number of people killed per year in the 2010s by these five categories of natural disasters in Figure 1. While hydrological disasters are a global concern, other types of natural disasters are more localized; geophysical disasters mainly impact Asia, biological disasters tend to affect African and Latin American countries, meteorological disasters impact much of the world except for North and Central Asia and Africa, and climatological disasters are less prevalent except for Greece, Portugal, Somalia, and the U.S., which experience severe wildfires. Since countries experience substantial variation in types and severities of disasters, efforts aimed at global collaboration around the mitigation and prevention of natural disaster can be challenging.

\section{Causes of Natural Disasters and the Role of Human Involvement}

Figure 2 illustrates the classifications of disasters based on two forces: natural forces and human involvement. By human involvement we refer to the degree to which people increase (or decrease) the threat of natural hazard through their interaction with nature and the ability of humans to prevent a hazard from becoming a disaster. Some types of disasters are a result of complex human activities. For instance, for industrial disasters, train wrecks, large scale digital hacking, terrorist attacks, and violent conflicts, high levels of human involvement are always a main cause. These types of disasters induced by human activities can be classified as (close to) a risk from Knight's dichotomy (Knight, 1921). Here we call it systematic uncertainty because its probability is less known compared to conventionally considered risks such as exchange rate risk, inflation risk, country governance risk, or technological change. ${ }^{2}$

Within the class of natural disasters, some disasters have underlying causes that consist of exogenous natural forces with low levels of human involvement. Geophysical and meteorological disasters are considered examples of these types of natural disasters. In Knight's dichotomy, these types of natural disasters are (close to) uncertainty (Knight, 1921), which we call unsystematic uncertainty to distinguish it from systematic uncertainty, which is more knowable. The occurrence and intensity of these natural disasters are unsystematic and uncertain, and thus it is difficult to predict and to prepare for them. Thus, the nature and extent of disaster preparation that should and could be undertaken is not always obvious.

The second type of natural disasters are the ones that have comparatively higher levels of human involvement including hydrological, climatological, and biological disasters than the first type. Since human activities contribute toward exacerbating or mitigating the underlying natural forces that affect the frequency and intensity of these hazards, they can be difficult to predict. There are, however, some estimable trends concerning their occurrence and intensity due to the complex interrelations between natural forces and human involvement. Therefore, this type of natural disaster is a mixture between unsystematic uncertainty (uncertainty from Knight's dichotomy) and systematic uncertainty (risk from Knight's dichotomy). ${ }^{3}$ While human involvement can be a critical part of these types of natural disasters, without natural forces, these disasters will not happen. Although people are often part of the cause of these types of natural disasters, they can also play a significant role in reducing the threat. 


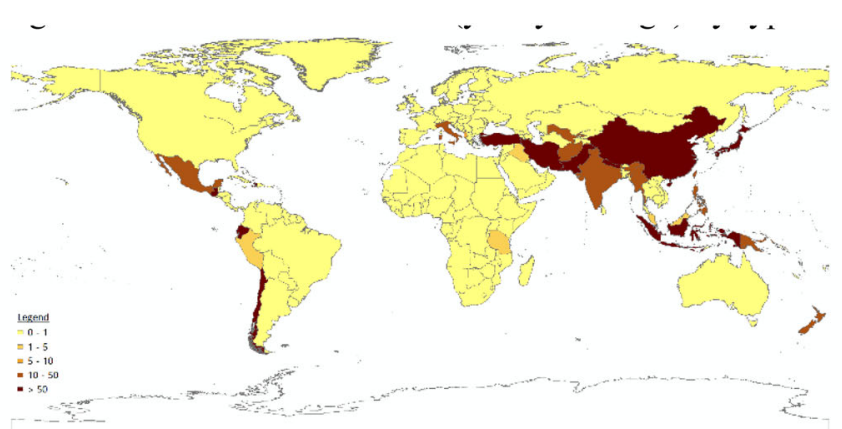

Geophysical disasters

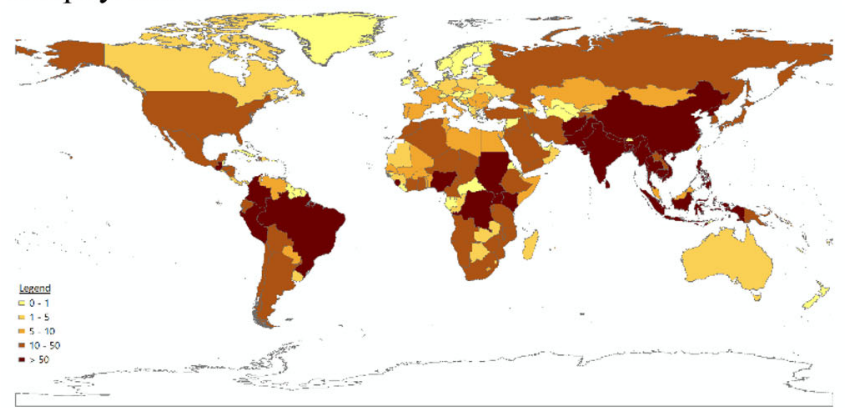

Hydrological disasters

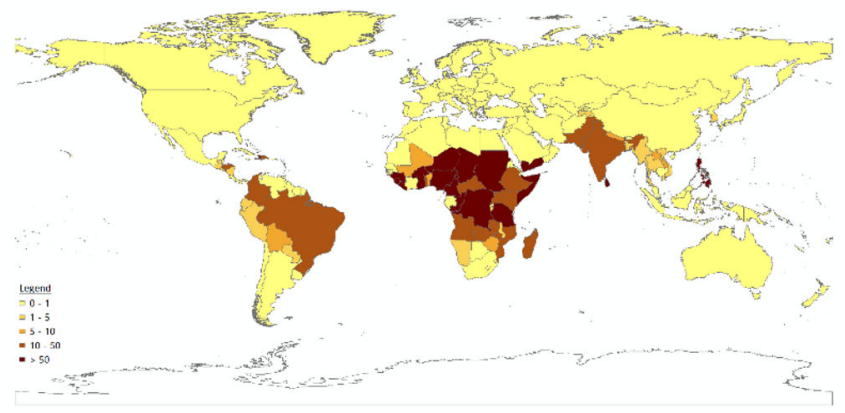

Biological disasters

Source: EM-DAT (2020).

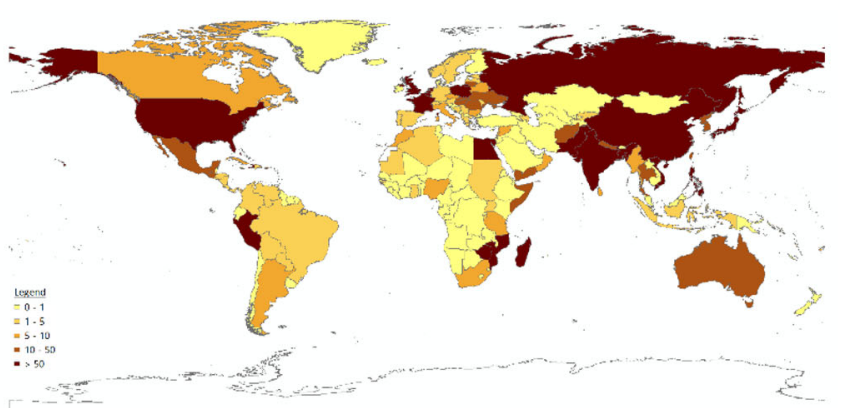

Meteorological disasters

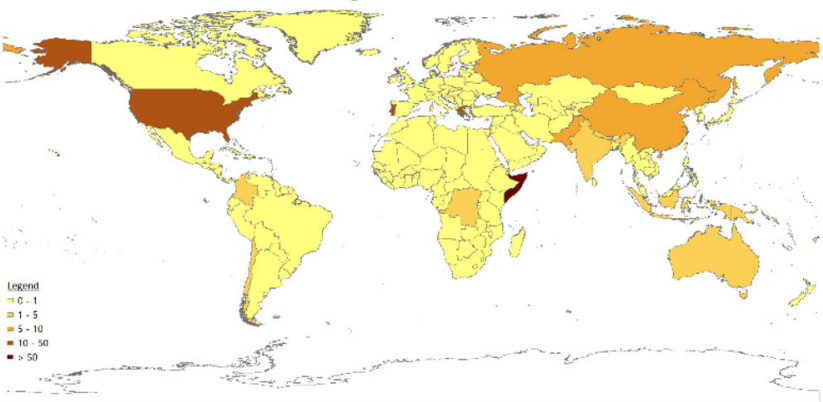

Climatological disasters

Figure 1 The number of killed (yearly average) by types of natural disasters in 2010s.

An example is the case of wildfires. Over the last few years, wildfires have been increasing in number and severity in parts of the western U.S., posing a major threat to business and society. In some cases, wildfires are caused by the interaction between business and nature. In Northern California, Pacific Gas \& Electronic (PG\&E) is directly responsible for at least, "five of the ten most destructive fires in California," between 2015 and 2019 (Penn, Eavis, \& Glanz, 2019). According to the director of the climate and energy policy program at Stanford University, the wildfires triggered by PG\&E's outdated wiring and equipment is "a failure of management and a failure of vision" (Penn et al., 2019).
Natural disasters often impact the broader business environment in a specific area or for a specific industry sector. For example, the volcano eruption from Eyjafjallajökull in Iceland between March and May of 2010 generated an ash cloud across large parts of Western Europe. This led to a major disruption of flights throughout Europe. Some firms were able to prepare during the lengthy eruption period. Korean Air drew up a contingency plan for this volcanic eruption, while many other carriers started cancelling their flights in Europe on April 15th. When the company's flight to London was redirected to Paris and then Frankfurt on April 15 th, the company secured hotel rooms and leased buses to cross passengers into the U.K. over the 


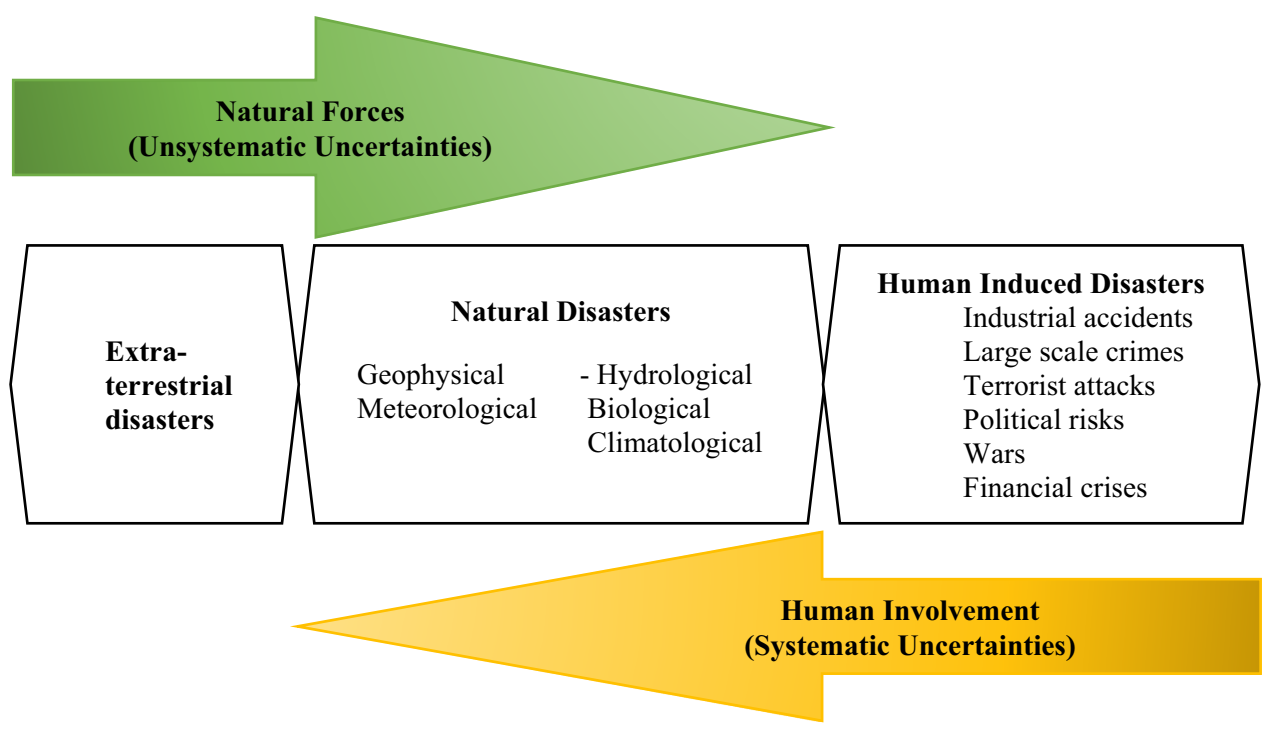

Figure 2 Types of disasters and human involvement.

Straits of Dover (Lee, 2010). While the direct effect of the volcanic eruption was likely confined to the airline industry, the eruption indirectly affected tourism, the hotel industry, and other businesses impacted by cancelled air travel.

\section{NATURAL DISASTERS AND IB THEORIES}

\section{Characteristics of Natural Disasters}

As shown in Figure 2, the causes of natural disasters are a mixture of human involvement and natural forces. For these reasons, we consider natural disasters as unsystematic uncertainties as opposed to systematic uncertainties that are exclusively affected by human action (or inaction) such as banking/currency crises, economic crises, political violence, terrorist attacks, and technological/industrial accidents. When it comes to the impact of both types of uncertainties, there are some similarities between the two types of uncertainties. Both types can have devastating impacts on victims, society, and the economy. A key difference, however, is the interaction between human involvement and natural forces making natural disasters (unsystematic uncertainties) difficult to predict and to understand in terms of timing, intensity, scale and scope of damages, and loss of life.

According to Courtney et al. (1997), uncertainty can be classified into four levels based on whether they are predictable and knowable: Level 1 (a clearenough future; a single forecast), Level 2 (alternate futures; discrete scenarios), Level 3 (a range of futures; a continuum bounded by a range); and Level 4 (a true ambiguity; virtually impossible to predict). Courtney et al. note: "[i]t (level 4 uncertainty) might not even be possible to identify, much less predict, all the relevant variables that will define the future" (1997, p.5, emphasis ours). Thus, natural disasters (unsystematic uncertainty) could be level 4 uncertainty, which is less predictable and knowable compared to systematic uncertainty. The impact of specific types of natural disasters may vary based on the characteristics of the disaster and the inherent uncertainty from natural forces associated with the event. First, in comparison to other types of disasters/crises, natural disasters tend to have a higher level of unpredictability, on average (Buckley, Chen, Clegg, \& Voss, 2020; Oh et al., 2020). For natural disasters characterized by a high level of human involvement, such as those associated with climate change, climatologists foresee a dramatic increase in disasters in hazard-prone areas and, as a result, greater risk to people and economic assets (Banholzer, Kossin, \& Donner, 2014; Visser et al., 2014). These trends are only expected to worsen in the foreseeable future. Nevertheless, it is impossible to predict the size of the impact, the location, or the timing of climatic disasters such as storms, floods, droughts, and wildfires. The main reason behind the unpredictability is that the underlying determinants of natural disasters are less predictable and knowable. This may be why natural disasters are often called "acts of God." Not only because of their exogeneous nature and unpredictability, but also because of their 
complexity. In short, humans cannot control nature but at times they can influence it.

Second, adding to Courtney et al.'s (1997) two dimensions, managers have a considerably low awareness of natural disaster threat. This lack of awareness and knowledge hinders managers with respect to allocating resources to prepare for and manage the threat of natural disasters. This causes delays in response and recovery and thus operational disruptions when major disaster events occur (Oetzel \& Oh, 2021; Webb et al., 2000). This lack of awareness (or low perception) may be attributed to the fact that managers doubt that they can manage or prepare for natural disasters, that the preparation and management of natural disasters is the role of private sector, and/or that the natural disaster will actually occur (Oetzel \& Oh, 2021; Slovic, 2000).

Third, the other important characteristic of natural disasters that distinguish them from other types of uncertainties is their geographic scope, which is more relevant to IB scholars but often ignored. Unlike hazards and uncertainties that directly affect locations confined by artificial borders and managed by governments, the natural forces behind natural disasters are oblivious to such human made limits (Yamori \& Goltz, 2021). As such, they can directly span different administrative and judicial controls affecting streets, towns, regions, countries, and the entire planet. A natural disaster event can directly damage the entire operations of a MNE, its subsidiaries, its supply chain partners, and/or its various stakeholders. In addition, each disaster event has a different intensity and geographic scope. If we include the indirect impact, the damage and geographic scope become difficult if not impossible to quantify.

\section{IB Theories and Managing the Threat of Natural Disasters}

Despite the obvious importance that the increased threat of natural disasters poses to IB, including the economic, social, and environmental costs to society, the IB literature is relatively quiet on the topic of natural disasters. One reason why natural disasters do not receive much attention in IB research is that they are considered outside the MNE managers' locus of control. Disasters are deemed the domain of natural scientists and government agencies, not managers of firms. Also, the (direct) impact of natural disasters is often highly localized while research in IB focuses more on country-level risks or larger geographic regions. Given the threat of cascading natural disasters, the wide geographic impact they can have, and the global interconnectedness of MNE operations, managers of MNEs cannot afford to ignore the threat. Rather, MNEs should develop their own plans and strategies for addressing the threat of natural disasters. Doing so is especially important since the public sector is not always equipped to respond effectively to natural disasters, particularly those that blur political and jurisdictional boundaries and/or national borders (Malhotra \& Kuo, 2008; Sobel \& Lesson, 2007).

Given this background, next we examine how several key IB theories might enable managers to formulate more effective strategies for managing the threat of natural disasters to MNEs and their operations. A challenge that managers face in preparing for and responding to natural disaster threat is that doing so requires them to invest in establishing relationships and formulating strategies and tactics that might never be used. If a disaster does not occur, establishing those capabilities may be seen as an "unnecessary cost" and a "wasted" expense. For these reasons, it is easy to delay or dismiss the decision to prepare for natural disasters. Since management and much of IB research focus on formulating strategies to reduce costs and increase the bottom line, convincing managers to invest in capability development for natural disasters requires a change in organizational awareness and managerial mindset.

To date, relatively little work in IB specifically examines risk management for natural disasters and some of the unique challenges they pose for strategy formulation, decision-making, and implementation in MNEs. Following several IB theorists (Forsgren, 2013; Kano \& Verbeke, 2019; Wolf et al., 2012), we choose three dominant perspectives/ theories (NIT, organizational capability view, and institutional theory) that are most relevant to formulating MNE's managerial strategies for managing and responding to external uncertainties. In addition, we include agglomeration economies and the risk diversification perspective due to their close relevance to MNE risk management strategies. We do not suggest that this is an exhaustive set of relevant theories. Rather, we focus on how several relevant theories in IB can contribute to our understanding of systematic and unsystematic uncertainties. Table 1 lists several core theories and ideas in IB research and details their (un)applicability for exploring systematic and unsystematic uncertainties. We do not intend to review these theories in detail. Rather, we point out key theoretical ideas and examine which 
Table 1 Applicability of IB theories in explaining systematic and unsystematic uncertainties

IB theory/view Key ideas to IB research

\begin{tabular}{ll}
\hline New & Distinguish location- and non- \\
Internalization & location-bound FSAs. Examine how \\
Theory & MNEs exploit, augment, recombine, \\
& and allocate those FSAs interfacing \\
& with CSAs to make efficient \\
& governance decisions for themselves \\
& and their relationships with \\
& stakeholders
\end{tabular}

Organizational capability view

Institutional theory

Agglomeration economies

Risk diversification
Consider MNEs as unique creators and orchestrators of capabilities. Examine how those capabilities are created and orchestrated across borders and help MNEs improve their international competitiveness

Consider MNEs' internationalization strategies as their adaptive process to host country institutional environments. Examine how various types of institutions govern the behaviors of MNEs
Various benefits of geographic agglomeration can be understood as the positive outcomes of vertical and horizontal linkages in terms of production, innovation, and knowledge exchange

View geographic diversification of MNEs across countries in the same

(Un) Applicability in explaining uncertainties

Systematic uncertainties

Systematic uncertainties are predictable in nature, and thus MNEs can develop their nonlocation-specific FSAs. MNEs can transfer and adjust them to the context of other locations facing similar uncertainties. Some of these FSAs are necessary when firms internationalize

If business environments are stable or predictable, managers can predict future business environments and develop their resource bundle by leveraging their existing knowledge-, experience-, and learning-based capabilities

Although the impact can be global, most of the systematic uncertainties occur within country borders.

Markets follow institutional mechanisms that are governed by formal and informal institutions. MNEs may anticipate uncertainties, understand the institutional environments in which they (plan to) operate, and develop their strategies and behaviors accordingly

MNEs consider way as diversification of financial portfolios to manage heterogeneous demand and input conditions. Examine how geographic diversification reduces overall MNE risks predictable uncertainties in their decision to enter a cluster to exploit the benefits of agglomeration or positive externalities

If predictable, MNEs can build optimal portfolios from their geographic locations to diversify risks

\section{Unsystematic uncertainties}

Due to the unpredictability and context specificity of the unsystematic uncertainties, MNEs need to work with local stakeholders to improve their local disaster management capabilities, as well as with supply chain partners to lower partners' opportunistic behavior and employ partners' FSAs. MNEs need to find mechanisms to improve their rationality and reliability Unsystematic uncertainties may disrupt existing markets. In addition, existing capabilities may be ineffective and/or irrelevant, hindering the ability to deploy existing capabilities within MNEs. Developing new capabilities requires resources and time; two factors that may be in short supply when an unanticipated disaster strikes

During unsystematic uncertainties, both formal and informal institutions either set inconsistent regulations and incentive structures or are insufficient for providing legitimacy pressures on markets and firms. In addition, unsystematic uncertainties are not limited in scope by country or other jurisdictional borders. Thus, the behaviors of MNEs can be more complex due to multiple institutional pressures in varying by locations and by capacity

Unsystematic uncertainties are often a by-product of the agglomeration of production and consumption activities. The endogeneity behind agglomeration and unsystematic uncertainties makes it difficult to understand the causality between location and risks If unpredictable, the optimal portfolio is difficult to determine. Some locations provide unique CSAs that may affect the operation of entire MNEs and influence risk at MNE-level. Establishing a subsidiary in a location that contributes to the value of the parent firm requires time and investment 
theoretical conditions can (or cannot) explain MNE strategic responses to systematic and unsystematic uncertainties.

\section{New internalization theory}

Several streams of internalization theory commonly provide strong theoretical logic for the existence of MNEs, their geographic and functional boundaries, and their organization structures in uncertain external environments (Rugman \& Verbeke, 2008). Evolved from transaction costs economics theory, NIT explains when and why MNEs prefer to internalize cross-border activities and develop capabilities related to IB rather than use market mechanisms (Narula et al., 2019). The initial version of internalization theory (Buckley \& Casson, 1976) emphasizes the rationality of decision-makers who can economize their decision-making based on cost/benefit calculations. Such an efficiency-based logic can readily apply to systematic uncertainty in the external environment, but it may be necessary to reconsider other behavioral assumptions when applying it to unsystematic ones.

NIT extensively considers the resource heterogeneity of firms and the geographic reach of certain firm-specific advantages (FSAs) (location-bound and non-location-bound FSAs) (Rugman \& Verbeke, 2003; Rugman et al., 2012), as well as behavioral assumptions (bounded rationality and bounded reliability) (Verbeke \& Greidanus, 2009; Verbeke \& Yuan, 2005). Like other strategic choices, disaster planning and response requires a combination of location- and non-location-bound FSAs. The characteristics of natural disasters that we discuss earlier make it difficult to transfer, deploy, and recombine FSAs effectively (Rugman \& Verbeke, 2003; Verbeke, 2003). For this reason, NIT may offer insights into MNE strategies for addressing the threat of both systematic and unsystematic uncertainties.

First, if the focal location provides unique and non-replaceable country-specific advantages (CSAs), NIT implies that strong FSAs enable MNEs to efficiently exploit those CSAs. Due to increased external transaction costs, when operating under uncertainties, MNEs and their subsidiaries need to develop and internalize strong FSAs including risk management capabilities. A challenge, however, is that the contextual specificity of natural disasters may limit the benefits of knowledge acquisition and experiential learning from conventional mechanisms such as international intra- and inter- organizational knowledge transfers and learning (e.g., non-location-bound FSAs). Therefore, MNEs should develop location-specific knowledge and capabilities that can be achieved through learning from and experience with various local partners. To identify local government capacity around disaster preparation and response, and to identify local nongovernmental organizations (NGOs), firms, and other actors that may serve as partners, require time and intentionality (Oetzel \& Oh, 2021). Ultimately, effective disaster management relies on these location-bound FSAs when MNEs cannot find alternative locations or partners.

Second, if CSAs can be deployed in other locations through affiliates and partners, MNEs need to govern and orchestrate them. How to govern those affiliates and partners will depend on first, location profile and second, non-location-bound FSAs (transferring, deploying, and recombining FSAs). Facing unsystematic uncertainties, cost-minimizing and benefit maximizing governance mechanisms can be explained using various versions of transaction cost economics and internalization theory. In the face of unsystematic uncertainties, the efficiency or profitability of governing mechanisms would not determine whether an MNE's affiliates and partners can provide their products and services as promised in such an uncertain business environment. This requires more than conventional risk management approaches for affiliates and partners. The absence or unpredictability of formal and informal market mechanisms during natural disaster events will likely increase opportunistic behaviors. It is also possible that affiliates and partners cannot keep their promises if they sustain severe damage. This is consistent with research showing that because of the unpredictability of natural disasters, supply chains cannot always be lean. Optimizing supply chains requires the ability to reliably forecast conditions (Kunz et al., 2017).

\section{Organizational capability view}

The organizational capability view (resource-based view, knowledge-based view, and their variations) explains how FSAs, such as superior capabilities around knowledge and learning, can be sources of competitive advantage. These capabilities or resources should be valuable, rare, and inimitable to constitute a competitive advantage (Barney, 1991; Mahoney \& Pandian, 1992). Over time, developing such internal capabilities and resources requires substantial managerial attention and valuable 
organization assets. If business environments are stable and generally consistent, firms can integrate and recombine existing resources and capabilities rather than develop wholly new FSAs.

In uncertain and changing environments, dynamic capabilities, when effective, can enable organizations to adapt to rapid changes in the environment. An organization's proficiency for developing dynamic capabilities may be a function of well-established organizational routines, its ability to learn from past experiences and, perhaps most importantly, experience with crises (Pavlou \& El Sawy, 2011; Teece et al., 1997). While prior experience and related dynamic capabilities can be valuable, they are not always relevant for rapidly changing and uncertain environments. One reason is that, when it comes to responding to natural disasters, conventional market-oriented capabilities and approaches may not be appropriate. Moreover, managers and their firms may not be able to integrate and recombine existing resources, nor develop new capabilities, in a short period of time. This is because disasters may disrupt existing markets rendering existing resources and capabilities ineffective or irrelevant.

Nevertheless, certain capabilities might be valuable and useful for addressing the threat of disasters. Thus, MNEs need to identify valuable skills and competencies and recombine their existing capabilities to adjust to new (temporal or permanent) environments. When threats are relatively certain and predictable (i.e., risk), MNEs can recombine their existing capabilities and resources in a relatively short amount of time (Kieser \& Koch, 2008). Thus, for systematic uncertainties, MNEs may recombine their resource bundle by leveraging their existing knowledge-, experience-, and learning-based capabilities that will help to improve bounded rationality under uncertainty. The Uppsala model of international expansion also suggests the potential benefits of exploiting experiential learning through the internationalization process that outweigh the risks and costs of doing business in new and unknown environments (Johanson \& Vahlne, 1977).

In contrast, managers facing unsystematic uncertainties may have a poor understanding of how their resources can be recombined and utilized. For managers, the unpredictability, rarity, and complexity of natural disasters may result in a lack of time and attention, bounded rationality, and cognitive biases around natural disaster management (Lockett et al., 2009). These may hinder learning and the ability to deploy existing dynamic capabilities within an MNE. Due to the episodic nature and rarity of natural disasters, firms are likely to forget the lessons learned in previous disasters (de Holan \& Phillips, 2004; Kano \& Verbeke, 2015; Oh, Shin, \& Oetzel, 2021). Firms need to use the lessons learned from experience with natural disasters regularly, otherwise they may unintentionally lose any gained knowledge (de Holan \& Phillips, 2004; Walsh \& Ungson, 1991). Firms may also forget the lessons learned because they may consider certain lessons to be relatively unimportant in performing daily business. Since managers cannot predict the next occurrence of a natural disaster or its intensity, they may give little attention to addressing the threat of natural disasters. What is perceived as uncontrollable may thus be ignored (Pearson \& Mitroff, 1993; Slovic, 2000).

The tendency to lose knowledge if not codified or updated is not unique to the threat of natural disasters. Empirical research on other types of unsystematic uncertainties identifies similar boundary conditions on experience and learning around risk management (Buckley et al., 2020; Oh et al., 2021). Thus, when it comes to unsystematic uncertainties, the application of experiential learning and the use of dynamic capabilities must be periodically revalidated for those firm-specific resources to be valuable and relevant.

\section{Institutional theory}

Institutional theory considers country- (or location)-specific environments as sources of opportunities and challenges when business environments are systematically uncertain. Institutional theory assumes the existence of formal or informal institutions that govern the behaviors of firms and people within country borders or other legally defined context (Kostova et al., 2008; Meyer \& Peng, 2016; North, 1990). In IB, the relevant institutions often govern the home country, host country, or home-host country dyad (Tihanyi, Devinney, \& Pedersen, 2012; van Hoorn \& Maseland, 2016). ${ }^{4}$

Much of the literature on institutional transition and change, and the impact of institutional change on firm strategy and organizational structures (Hoskisson et al., 2000; Peng, 2003), focuses on events in transition economies and emerging markets and those occurring because of political regime changes. Institutional changes such as these are outcomes of human activities and may be somewhat more predictable based on various country- 
level (or sub-national-level) political, economic, and social factors. Most catastrophic natural disaster events occur across those artificial borders, raising issues around national sovereignty and jurisdictional control. Therefore, during catastrophic natural disasters, collaborations across locations and over levels of hierarchy are difficult as expectations and impacts (even from the same event) are different across countries and societies.

During and after natural disasters, markets and firms can have different governing mechanisms and goals from those set by formal or institutional institutions in a country or society. It is not rare to observe panic buying and price gouging for essential goods during natural disaster events, such behaviors are very different from market mechanisms or social norms observed in normal times (Oh \& Reuveny, 2010). Thus, because both formal and informal institutions either set different regulations and incentive structures during and after natural disasters (e.g., new institutional economics), or are insufficient for providing pressures for legitimacy on markets and firms due to chaos and unpredictable changes (e.g., neo-institutional theory), institutional theory may not be sufficient for explaining the strategies and behaviors of firms in case of unsystematic uncertainties. The behaviors of MNEs can be more complex as they confront multiple, and sometimes conflicting, institutional pressures set by different sovereignties (Hillman \& Wan, 2005; Westney, 1993).

Similarly, while not often considered a part of institutional theory, other relevant views such as the liability of foreignness (Zaheer, 1995), psychic distance (O'Grady \& Lane, 1996), and the CAGE model (Ghemawat, 2007) assume that home country MNEs, or MNEs from neighboring countries, can economize their cost advantages based on institutional factors and psychic closeness. Specifically, these approaches assume that MNEs lower various costs, such as searching, monitoring, and coordination costs, by locating their operations in countries that provide better institutional and locational factors or closeness. While home country MNEs may have better knowledge about a government's capacity in dealing with natural disasters, the applicability of both formal and informal institutions would be limited in the case of natural disasters because the impact of natural disasters does not depend on the nationality or headquarters (HQ) location of MNEs.

\section{Other relevant theories}

Among many other theories/views, we find that agglomeration economies and the risk diversification perspective are most relevant to natural disaster management. First, the recent focus on economic geography in IB as it pertains to vertical relationships (value chains or global factories) considers MNCs as a coordinator of activities in different locations. From that perspective, the optimal location and ownership strategies are chosen by quantifying factors such as trade costs, economies of scale, factor endowments, and efficiency as well as firm-level heterogeneity (Beugelsdijk et al., 2010; Buckley \& Ghauri, 2004). However, this approach for identifying the optimal location and ownership strategies would not hold in the case of natural disasters because some of their underlying factors are not easily quantifiable.

In addition, the central ideas in optimal location and ownership choices in economic geography are based on agglomeration economies. Agglomeration economies are positive externalities from the geographic clustering of industry. The benefits from clustering include technology and knowledge spillovers, low production and procurement costs, and low search costs from geographic concentration (Shaver \& Flyer, 2000). The benefits can vary by a firm's competitive position and thus the most competitive firms may internationalize earlier than other firms (Helpman, Melitz, \& Yeaple, 2004; McCann, 2011). As we discussed in a previous section, some types of natural disasters are biproducts of the agglomeration of human and industrial activities. For instance, the impact of natural disasters is likely to be much higher in urbanized and highly populated areas where businesses leverage their economies of scale (Oh et al., 2020; Perrow, 2011). The endogeneity behind agglomeration and the occurrence and impact of natural disasters makes it more difficult to analyze the causality between location and disasters. In turn, it becomes more difficult to recommend the optimal location and ownership strategies of MNEs when we use country or location as a level of analysis.

Second, the finance-based portfolio approach provides a unique view on risk diversification for MNEs. That is, engaging in foreign operations reduces the MNE's corporate risks (Rugman, 1976) when economic cycles in different geographic areas are not perfectly correlated. In such cases, increased overseas operations may help an MNE offset 
increased risk in one market because the risk in an MNEs' total investment portfolio is diversified across geographies. The benefits of diversification include stabilizing revenue streams from heterogeneous demand conditions across countries (Rugman, 1976) and transferring factors of production across countries to exploit differences in input costs, exchange rates, and tax rates to achieve operational flexibility (Allen \& Pantzalis, 1996; Belderbos et al., 2020).

However, if a country or location offers an MNE non-replaceable CSAs, the disruption of a subsidiary's activities can interrupt the operation of the MNE as a whole, at least in the short-term. Even in the case that CSAs are replaceable with those in other locations, establishing a subsidiary that contributes to the value of the parent firm (i.e., portfolio) requires time and investment. Thus, if managers have knowledge about uncertainties and can anticipate them, they can gradually reconfigure their locational portfolio to balance the benefits and risks of their investments. In contrast, when confronted with unsystematic uncertainties, MNEs cannot quickly nor easily reconfigure their subsidiary location portfolios. In that case, risk diversification through location portfolio alone cannot fully optimize the risk exposure of MNEs to unsystematic and unpredictable uncertainties. It does, however, suggest the importance of establishing alternative supply chains that can be utilized in the case of natural disasters.

\section{Application of New Internalization Theory to Natural Disaster Management Strategies}

IB research is well suited for addressing natural disaster management and business continuity since complex global challenges tend to require interdisciplinary research and insights; one of the strengths of IB (Sullivan \& Daniels, 2008). In particular, NIT is known for its resiliency, flexibility, and validity in analyzing MNEs and their operations and explaining a wide range of recent IB phenomena (Narula et al., 2019; Rugman \& Verbeke, 2008). In this section, we will examine how NIT supports MNE managers' decision-making for the establishment of alternative supply chains and multi-sector partnerships for MNEs facing natural disaster risks and provide examples.

The notions of bounded rationality and reliability are core components of NIT theory. Verbeke and Yuan (2005) outline the key sources of both why and how they relate to IB research. Bounded rationality, as it relates to decision-making in
MNEs, relies on incomplete information, limited management information processing capacity, and headquarters and subsidiary-level conflicts that arise when organizations suffer from biased decision-making that may stem from a variety of sources. Natural disasters often generate unusual market imperfections making it difficult for managers to strategize and, thus, for firms to transfer, deploy, and recombine their FSAs.

In contrast to bounded rationality, bounded reliability refers to the inability of managers to make good on open-ended promises (Verbeke \& Greidanus, 2009). Bounded reliability builds on the observation that individuals may fail to uphold their commitments, but they do not necessarily do so out of opportunism. Good faith failures appear responsible for the bulk of unfulfilled commitments in and around firms (Kano \& Verbeke, 2015; Verbeke \& Greidanus, 2009). For example, managers may reprioritize their organizational objectives. It is not uncommon, for instance, for managers to consider disaster management as essential after a major crisis. As time goes by, however, managers and their organizations may begin to forget past experiences. Day-to-day pressures may eventually lead managers to downgrade disaster planning as a priority. Time discounting bias may lead managers to place a lower value on future events than on more proximate ones (Frederick et al., 2002; Verbeke \& Greidanus, 2009). Thus, disaster preparedness will not have a priority in decision-making unless managers foresee natural disasters as a significant threat. Moreover, experience with low impact natural disasters may lead managers to underestimate and potentially ignore the threat of natural disasters (Oetzel \& Oh, 2014; Verbeke \& Greidanus, 2009).

The unpredictable, unknowable, and contextualspecific nature of natural disasters can challenge the rationality of managers because of incomplete or limited information, and subjectivity in information processing and decision-making about natural disasters (Verbeke \& Yuan, 2005). Organizations in complex business environments with high levels of uncertainty need to have higher levels of information processing abilities to make quality decisions (Dess \& Beard, 1984). However, managers will neither have the same levels of access to an MNE's resources nor enough time to develop new resources during a disaster event. Thus, with high levels of bounded rationality, managers may rely more on the reliability of their partners. 
Access to valuable knowledge is at the heart of formulating effective responses for managerial dilemmas. Without trust-based relationships, it is unlikely that one organization operating alone can develop and implement a disaster response strategy. Trust is also critical for MNEs seeking to establish relationships with secondary stakeholders, such as various government agencies, NGOs, and communities, who do not have direct contractual safeguards or economic incentives to partner with MNEs (Kano \& Verbeke, 2015).

An understanding of the factors that create biases in decision-making around natural disaster preparation and response can lead to insights into ways of responding to natural disasters. Researchers in the natural sciences, policy sciences, and IB generally agree that the effective development and coordination of alternative supply chains and multi-sector partnerships (characterized by high levels of trust among partners) is necessary well before a realized disaster. Doing so in advance is vital for overcoming biases in decision-making and forming effective strategies that can be successfully implemented (Han et al., 2017; Kano \& Oh, 2020; Oetzel \& Oh, 2021).

\section{Alternative supply chains}

While trustworthy relationships with affiliates and partners are always valued, they can be critical when it comes to disaster management. For example, early in the COVID-19 pandemic there was a drop in vehicle sales, which in turn led auto manufacturers to cut their orders for computer chips. As some countries began to recover from COVID-19 in 2021, there was a rapid increase in demand for vehicles. Automakers subsequently faced a major challenge since semiconductor producers already agreed to sell their chips to electronics and IT firms. Consequently, the global shortage of semiconductors caused delays and cuts in production throughout the global automotive industry (Vakil \& Linton, 2021).

MNEs that established trusted relationships with affiliates, partners, and suppliers prior to the shortage of chips, may subsequently enjoy increased knowledge and lower search costs and opportunistic behaviors when working with others. The shared knowledge and collective insights common between an MNE and its trusted partners can be invaluable in a crisis. Thus because of these relationships, MNEs will be able to achieve both resource flexibility as well as coordination of those flexible resources (Sanchez, 1995).
Additional examples will illustrate the difficulties that MNEs face in the case of natural disasters and the importance of establishing and coordinating trust-based relationships with alternative supply chain partners. Xirallic pigments, a specialty paint for cars, has been manufactured only in the earthquake zone of the March 2011 Great Tohoku Earthquake and Tsunami in Japan. At the time of the earthquake/tsunami, a range of Japanese, U.S., and European automakers quickly found it impossible to produce certain colors of their vehicles without this important paint additive (Canis, 2011). For its part, Merck Chemicals publicly stated that it would immediately supplement its production of the pigment in Japan with production at a new facility in Germany (Canis, 2011). In reality, however, it took a year to begin a second Xirallic production line in Germany (Tajitsu, 2016).

General Motors, which did not produce its vehicles in Japan, also had to close a plant in Louisiana, layoff its workers in New York, and cancel some shifts in South Korea, Spain, and Germany due to shortages in components. To help its suppliers during their recovery in Japan, General Motors tried to get key components that were in short supply. The CEO of General Motors, Dan Akerson, told a reporter "we can't rely on one source [of suppliers]. So, I picked up the phone, I called the CEO of Freescale and I said, 'I know you make chips of this type'" (Automotive News, 2011). Rob Mills, director of GM Components Holdings underlined in an interview, "I know who to call in the organization, who works well in crisis, who has the right skill set, who has the stamina to survive in the environment, and who also has know-how to work within their function and across the functions" (Sheffi, 2015). After the disaster, several automotive companies developed supply chain databases and required prospective partners to include alternative sourcing plans for parts (Tajitsu, 2016).

\section{Multi-sector partnerships}

Disaster management experts note that the development of effective multi-sector collaborations is critical. Leading experts argue that "collaboration is a necessary foundation for dealing with both natural and technological hazards and disasters and the consequences of terrorism" (Waugh \& Streib, 2006: 131). Multi-sector collaborations involve a mix of actors from public, private, and civil society organizations. Given the location specificity of natural disasters and actors, MNEs 
need to develop multi-sector collaborations in each risky location. Collaborations that are committed to addressing a shared concern, and that are guided by vision and effective strategy, are those most likely to succeed (Waugh \& Streib, 2006).

Yet, effective coordination and preparation are not easy to achieve. Research shows that multisector partnerships often experience difficulties maintaining ongoing partner participation (MacDonald et al., 2019). Furthermore, collaborative decision-making in complex environments depends on various factors such as sharing common values and goals, reciprocity, lateral communication, information sharing, continual feedback, and learning (Bundy et al., 2018; MacDonald et al., 2019; Woods, 2009).

Researchers long recognize the value of multisector collaborations noting that relationships and networks may enable managers to leverage local stakeholders and their resources (Hennart, 2009; Teegen et al., 2004). For managing disasters, however, MNEs must be able to move away from wanting to "control" a partnership and structure it for its own ends. Rather, any collaboration should be designed to create shared social and economic value. Organizations that come together with complementary capabilities, which share a vision for improving resilience to disasters, and that are not dominated by the control of one entity or sector, will likely be most effective preparing for, and managing responses to, natural disasters (Dahan et al., 2010). Where possible, these multi-sector networks will provide complementary resources to subsidiaries, particularly for those that are able to recombine those external resources with their existing FSAs. To do this, the subsidiary must be sufficiently embedded in the local context (Dhanaraj et al., 2004). It will enable them to reserve their financial and temporal resources to develop new FSAs that can be leveraged during challenging times.

When Hurricane Katrina hit the Gulf Coast of the United States in August of 2005 and devastated New Orleans, Louisiana, it was a watershed moment for the U.S. MNE Walmart. Based on employee initiative and its core competencies in logistics and supply chain management, the company provided water and other supplies to survivors before the local and state governments were able to do so (Henderson \& Weber, 2016). Realizing both the devastation wrought by Hurricane Katrina, their unique ability to help given their core competencies, and the outpouring of goodwill following their actions, Walmart has made disaster preparation and response central to its operations (Henderson \& Weber, 2016). Yet, even a company the size of Walmart cannot go-it-alone. When providing relief after a 2017 earthquake in Mexico City, or preparing for natural disasters in other countries, Walmart needs both short- and longterm partnerships that can be leveraged as needed (Business Wire, 2017).

Considering both cases (i.e., alternative supply chains and multi-sector partnerships), to be effective MNEs need to build strong local and international relationships to address the complex managerial and logistical challenges related to disaster management. All partners must share a high degree of trust and common interests. This requires temporal and financial investments to develop and identify appropriate suppliers and partners. Another benefit of reliable relationships is that they can improve organizational decisionmaking and lower bounded rationality.

\section{GEOGRAPHIC SCOPES AND MNE RISK MANAGEMENT STRATEGIES}

Internalizing and recombining location-bound or non-location-bound FSAs to develop trust-based relationships with affiliates, partners, and stakeholders would be beneficial to MNEs for the preparation of and coping with high impact natural disasters. The benefits of trust-based relationships, however, would depend on the levels of MNE risk exposure. MNEs face exposure to high levels of natural disaster threat when the geographic scope of a disaster is large and/or when the MNE creates value through the geographic scope of its operations. The first case is more straightforward. MNEs face a greater threat when the geographic scope of a disaster is large, since it is more likely to impact an MNE's business environment. However, high impact natural disasters, with a low geographic scope, in a key location for a MNE, can also disturb its entire operations and lower its performance. We describe such a situation in our earlier example of the automotive industry, post-earthquake and tsunami in Japan in 2011. In the second case, MNEs with a large geographic footprint are more likely to find themselves in one or more disasterprone locations and thus exposed to natural disasters. For these reasons, the effectiveness of an MNE's risk management strategy, including the use of alternative supply chains and multi-sector 
partnerships, depends on the geographic scope of both natural disasters and MNEs.

It is also important to note that disasters in one country can impact both local and IB environments. At the site of the disaster, MNE subsidiaries risk damage to infrastructure, discontinuity of operations, and threats to employees' health and well-being. At an international level, MNE supply chains may be threatened in areas far from the disaster site. Natural disasters with a large geographic scope may defy the sovereignty of borders, complicating the management of, response to, and severity of a disaster. These issues are likely to be magnified by different government policies and cultural norms across countries. This illustrates the importance of public sector cooperation and coordination for addressing (or failing to address) an international crisis involving multiple country governments, it is also possible for a natural disaster in a single country to create ripple effects across global supply chains.

In Figure 3, we propose strategies that managers of MNEs may employ at varying levels of geographic scope of MNEs and natural disasters. The horizontal axis is geographic scope of MNEs indicating whether the geographic reach of their FSAs and operations are mainly location-bound FSAs (low geographic scope) or non-location-bound FSAs (high geographic scope) (Rugman et al., 2012). The vertical axis is the geographic scope of natural disasters indicating the prevalence of natural disaster threat in potential locations of MNEs.

\section{Avoidance Strategy}

Quadrant 1 of Figure 3 shows the case of localized natural disaster threat and low geographic scope of

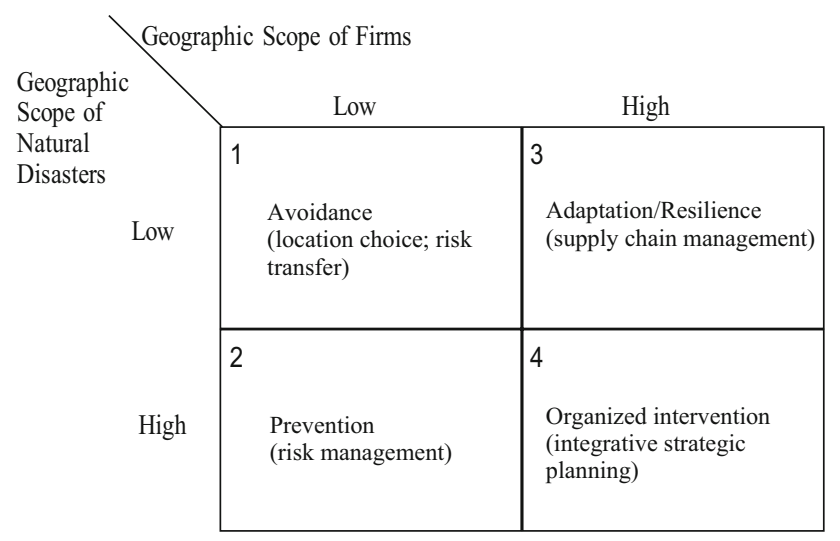

Figure 3 Geographic scope and MNE disaster management strategies. the MNE. Since the geographic scope of disasters is low and the MNE's FSAs are bounded by location, the firm can choose a safe location where it can exploit, utilize, and combine its location-bound FSAs and CSAs. Thus, the MNE can adopt an avoidance strategy for the threat of natural disasters and dramatically reduce or even eliminate disaster threat by divesting from the high-risk locations. Because the scope of natural disaster risk is low, it would be more cost efficient for MNEs to avoid a risky location and choose a safer one. In this case, the MNE may find a safer location in which the MNE can access location-bound FSAs and recombine them with its existing FSAs.

In some cases, an avoidance approach aimed at removing the source of threat may greatly reduce the probability of a disaster (Alcacer \& Herman, 2012; Jüttner et al., 2003). However, as discussed in earlier sections, many types of natural disasters are unsystematic and unpredictable uncertainties, so it is possible that at some point in the future, once relatively safe locations can become affected by natural disasters. Thus, MNEs may also need to insure their investments from uncertainties. In addition, if MNEs are unable to avoid operating in a particular location because they need to access unique and non-replaceable location-bound FSAs, or country-specific factors, a MNE may leverage insurance mechanisms. Even in that case, however, climate change is leading insurance companies to reduce current levels of coverage or raise rates to unaffordable levels in the future (Tesselaar et al., 2020).

\section{Prevention Strategy}

Quadrant 2 in Figure 3 shows the case of natural disasters with a high geographic scope and MNEs with a low geographic scope. While MNEs may operate in specific geographic areas due to locationbound FSAs, if the threat of natural disasters with a large geographic scope is high, reducing disaster threat will likely require more than avoidance. This is because it would not be easy for MNEs to avoid risky locations; rather MNEs need to develop their prevention strategy at a subsidiary level. Despite efforts to improve strategic planning, the reality is that few MNEs have adopted detailed natural disaster plans (Oetzel \& Oh, 2021). While managers of MNEs may cite resource constraints as a barrier to preparing for disasters, the long-term costs (and forgone benefits) of employing an avoidance approach could be large. Also, since this type of MNE relies on location-bound FSAs, a prevention 
strategy for the threat of natural disasters can focus on the MNE's subsidiaries in specific locations. Given the context specificity of location-bound FSAs and disasters, and resource constraints, it is not likely that MNEs can leverage prevention strategy in other locations.

Disaster preparation requires enhancing organizational flexibility to adjust and scale up as needed, so that MNEs can respond in a timely manner (Vakis, 2006). In addition, subsidiary managers may need to gather information or knowledge from various local stakeholders to understand how a natural disaster is likely to impact the subsidiary and what the potential impacts are on the MNE. Once a disaster occurs, it may be too late to identify appropriate sources of information (bounded rationality) or develop the relationships needed to coordinate effectively with government, non-government, and other actors as needed (bounded reliability). Thus, establishing multi-sector partnerships should be a centerpiece of any disaster prevention strategy.

\section{Adaptation Strategy}

Moving to the right side of our $2 \times 2$, we focus on Quadrant 3 in Figure 3 that illustrates the case of low geographic scope of natural disasters and a high geographic scope of the MNE. Although the geographic scope of disasters is low, an MNE utilizes and recombines its non-location-bound FSAs across several locations potentially exposing the MNE to locational disaster threat. In situations where disasters may damage subsidiaries or their suppliers in specific locations, and/or temporarily interrupt firm operations, the entire operation can be affected. Thus, MNEs need to minimize the potentiality of disruptions and maximize their resilience to external threats. Industry differences are also important in considering how to adapt. The ski industry, for instance, is highly vulnerable to droughts and slightly warmer temperatures. Between 1999 and 2010, the industry lost approximately one billion dollars in revenue when demand for skiing dropped substantially due to warmer temperatures and uncertain snowfall (Rivera \& Clement, 2019; Tashman \& Rivera, 2016). The retail sector tends to experience significant financial losses after natural disasters while manufacturing and construction may experience gains (Zhang et al., 2009: 40). These differences suggest the need for industry appropriate adaptation strategies.
Resilient organizations are those that can survive and cope with disasters with minimum impact and damage to their operations and employees (Berke \& Campanella, 2006; Cutter et al., 2008). When the geographic scope of natural disasters is low (i.e., threat is relatively low) and the MNE uses nonlocation-bound FSAs, MNEs will be able to find safer locations for their subsidiaries and choose alternative partners to improve flexibility and diversify risk. Since research shows that businesses that serve large regional or international markets recover more quickly than those that are locally focused (Webb et al., 2000), the ability to diversify risk geographically is a significant advantage for MNEs. MNEs can increase their resilience and ability to adapt to natural disaster threat by establishing alternative and/or flexible supply chains (Cutter et al., 2008; Hajmohammad \& Vachon, 2016). They may also try to reduce financial pressures caused by business disruption. High levels of leased assets reduce flexibility and increase pressure on firms to generate revenue (Zhang et al., 2009: 42). While MNEs may strive to reduce inventory under normal conditions, in the event of a disaster, it may be difficult to replenish supplies leaving global supply chains vulnerable to disruption. The value of increased organizational and financial slack can help maintain business continuity and enable MNEs to engage in stewardship activities that facilitate disaster relief and recovery.

\section{Organized Intervention Strategy}

Finally, in Quadrant 4, we have the case where the geographic scope of both firms and natural disasters are high. As such, MNEs are likely to be affected by natural disasters in multiple locations. In this situation, MNEs develop their non-location-bound FSAs and recombine them to improve their performance at both the subsidiary- and MNE-levels. This case is highly complex for MNEs because the types of challenges faced by subsidiaries, partners, and stakeholders are different in each location. It will be the roles of subsidiary level managers to resolve any difficulties they have in each location by collaborating with local stakeholders. Managers will also need to coordinate and address any issues in their subsidiaries or with their supply chain partners. In this case, managers at HQs must consider developing an organized intervention strategy that considers both MNEs as a whole and their subsidiaries, partners, and stakeholders. This includes intervening in various aspects of MNE operations to analyze and integrate unique challenges from the threat of 
natural disasters in its various locations and transform them into its strategic planning and implementation. One of the goals of this approach is both to prevent and to mitigate the threat and impact of natural disasters. Recognizing that it is not always possible to avoid all the negative effects of disasters, managers must also develop coping skills that may aid in the recovery process.

Root causes of disastrous impacts of natural hazards can only be tackled if disaster prevention and response are incorporated in both development and environmental strategies (Wijkman \& Timberlake, 1984). To achieve this, an MNE needs to regularly examine the specific challenges faced by each of its operating units, the unit's contribution to other units within the MNE, and the functioning of the entire MNE. The MNE should develop and implement integrative programs to intervene quickly when its units are (expected to be) affected by challenges (Skoufias, 2003). The organized intervention strategy should integrate both cost-driven and value-driven approaches. For the cost-driven approach, because of the high threat levels, it is necessary to control and coordinate operations from HQs to improve overall preparation and resource allocation throughout an MNE. Doing so will enable the MNE to achieve high levels of resilience. For the value-driven approach, because of the importance of non-location-bound FSAs in MNE's operations, it requires value sharing and participation from subsidiaries and partners to establish intra- and inter-organizational reliability in its supply chains.

\section{PREPARING FOR AND MANAGING NATURAL DISASTER RISK}

The barriers to effective disaster management strategies are largely managerial. Managers must be aware of and value the importance of disaster preparation and be willing and able to establish risk management programs. Such programs include strategies explained in previous sections such as reaching across sectors to form partnerships that can be leveraged when needed and building alternative supply chains, among others. In terms of the specific tactics associated with preparing for and responding to natural disasters, firms may undertake a wide variety of activities including (but not limited to): conducting an assessment of firm vulnerability, establishing a natural disaster response plan, training employees about natural disaster preparedness, purchasing insurance for business discontinuity, and arranging to move business operations temporarily to another location, among others (Tierney et al., 2001; Webb et al., 2000). Once the disaster strikes, established evacuation and business continuity plans may yield dividends. In disaster-prone areas, preparation can also be a valuable source of competitive advantage. Assuming there is a desire to prepare, in this section we review how IB research broadly, and NIT specifically, inform disaster risk management based on the programs and tactics described here. We also highlight the key disaster management issues for MNEs and discuss areas for future research.

\section{Research on Disaster Preparedness}

Preparedness is at the core of any effective strategy for managing uncertainties. While disaster response and recovery plans are also vital, effective strategies and tactics must be designed a priori, not post hoc disaster. For MNEs, part of preparedness includes establishing multi-sector partnerships and, in many cases, designing alternative supply chains. To coordinate with and learn from multi-sector partnerships, improving reliability and trust is a key antecedent of natural disaster preparedness. However, having reliability and trust with multi-sector partners is challenging and cannot be achieved in the short term (Alerts \& Mysiak, 2016). Therefore, managers need to find ways to overcome bounded reliability problems that arise from various sources such as reprioritization, unlearning, and divided engagement (Kano \& Verbeke, 2015; Verbeke \& Greidanus, 2009) that hurt managers' commitments to preparedness. Clearly, more research is needed on the effectiveness of various risk management activities and crisis management more broadly.

\section{Leadership, entrepreneurship, and philanthropy in disaster preparedness}

While organizations have tended to rely on government to address disaster risk (particularly in the U.S.), even the best public sector organizations face challenges addressing the scale and magnitude of natural disasters. In fact, MNEs are often better positioned to respond to natural disasters than the public sector alone given MNEs' ability to coordinate decentralized activities and share knowledge effectively and quickly (Sobel \& Leeson, 2007). Except for Oetzel and Oh (2021), research on this topic mainly focuses on firm divestment (Oetzel \& Oh, 2014; Oh \& Oetzel, 2011), corporate social responsibility (Tilcsik \& Marquis, 2013), and 
entrepreneurial activities (Williams \& Shephard, 2016), as strategic responses to natural disasters and their aftermath.

However, given the growing, and seemingly unavoidable increase in natural disasters, firms need to transform their business processes proactively to prepare for natural disasters and to contribute to sustainable development. Such transformation requires the awareness and experience of top executives (Oetzel \& Oh, 2021) and their leadership and entrepreneurship towards sustainability and business continuity. Future research should examine how organizational awareness and managerial mindset affect natural disaster preparedness and analyze various factors that may moderate those relationships.

\section{Coordination with internal and external activities}

For MNEs and IB, disaster preparedness also requires the coordination of various location-specific and non-location-specific activities. They must be formed well in advance of a crisis. As one public official stated at a conference for building disaster resilience, once a crisis starts it is too late to make friends (USCCF, 2019). Thus, one area for future research is to investigate whether and how an MNE coordinates its internal and external activities given the threat of natural disasters. For instance, high levels of coordination may reduce both bounded rationality and reliability problems. Coordination requires shared goals, knowledge, and capabilities within MNEs and their various stakeholders. Managers must determine whether disaster risk preparation and management capabilities can be transferred throughout the corporation and its stakeholders, or whether these capabilities are context-specific (Oh \& Oetzel, 2017). Ideally there will be some information and capabilities that can be useful in multiple locations, but other strategies and tactics may only be applicable in certain locations.

Finding context specificities will enable a deeper understanding of the factors determining disaster preparedness. These factors may include industry and disaster characteristics as well as conventional location and firm characteristics. ${ }^{5}$ For instance, in the extractive industry, MNEs are often well prepared for various challenging environments because of their exposure to harsh and remote natural environments and their expertise in engineering and geology (Shapiro et al., 2018). Yet, knowledge, learning, and partnerships that are valuable in one location may be irrelevant in another. For this reason, various factors such as the type of natural disasters, institutional and cultural norms, and organizational characteristics could limit the coordination of internal and external activities across borders.

As another example, while some firms many be affected at the local level, platform-based and electronic communication businesses are likely to be directly impacted by hydrological and geophysical disasters. This is because these types of disasters can destroy data storage facilities and network infrastructure. Since platform-based and electronic communication businesses rely less on unique location factors and more on connectivity across different locations, these businesses need to develop non-location-bound risk management capabilities that can translate across different locations and partners. This requires the extensive orchestration of external activities with other organizations such as infrastructure providers, contents providers, producers, and other participants such as those in logistics, payments, and electronic device manufacturing.

\section{Research on Cross-organizational Collaborations}

For IB and MNEs, one of the key managerial challenges is to identify and develop informal cross-organizational collaborations in disasterprone areas where the MNE or its subsidiary is located. Partnerships are generally critical for effective firm response to risk since disaster management efforts are generally too complex for a single organization to tackle in isolation (Chen et al., 2013). Cross-organizational collaborations can also lead to innovative approaches and even new business models for addressing these risks (Dahan et al., 2010). Building solid cross-sector relationships as described here, is not always easy. Also, assuming these collaborations are valuable, how should managers go about building such collaborations? A first step is to identify trustworthy partners.

\section{Identifying trustworthy, knowledgeable partners}

Despite their value, identifying trustworthy partners and collaborators can be challenging. Which partners have the relevant information and expertise? Are they trustworthy? These are critical questions since in the case of an emergency like the occurrence of a natural disaster, an organization cannot experiment with knowledge acquired from unreliable sources, of unknown relevance, and uncertain trust worthiness (Goerzen \& Beamish, 2005). Yet, reliable know-how can be difficult to 
find in rapidly unfoldingly crisis (Waugh \& Streib, 2006). For those MNEs that have trusted relationships in place prior to a crisis, managers may be able to improve managerial decision-making and lower bounded reliability. Given their importance, more research is needed to understand better how MNEs find trustworthy partners and what factors make a partner trustworthy when preparing for disasters and crises.

\section{Knowledge acquisition through partner diversity}

While the benefits of multi-sector collaboration and the value of investing in relationships and trust building cannot be overstated, it is important to recognize that organizations must engage in an ongoing search for new insights and knowledge. Relying solely on a few sources for information may create biases in decision-making. There is a danger that once organizations establish their processes through repeated ideas and actions, it is very difficult to change these processes quickly in the face of new knowledge (Walsh \& Ungson, 1991). Because of the issues noted here, several studies show that high-level partner diversity can improve problem-solving capacity (Arslan et al., 2021; Beckman \& Haundschild, 2002). Thus, further research can shed light on whether the diversity of a MNE's partners lowers the bounded rationality (improves managerial decision-making) for managing the threat of natural disasters. Also, it would be valuable to know whether a more diverse set of MNE partners improves top managers' decision-making under the threat of natural disasters. If partner diversity is valuable, it would then be important to know how to control and coordinate such diverse partners and leverage their unique knowledge sets. Such capabilities could become valuable non-location-bound FSAs.

\section{Working with stakeholders}

Research on stakeholder management emphasizes the value of maintaining good relationships with stakeholders for improving reputations and lowering potential conflicts. The reasons for doing so are compelling since multi-sector partnerships can take on challenges that cannot be tackled by one organization or sector acting alone. Yet, stakeholders in different sectors have different identities and interests that do not always align with those of MNEs and other stakeholders (Caldwell et al., 2017).
While managing different stakeholders is challenging, accessing and utilizing complementary capabilities and resources of partners in multisector partnerships can be an innovative way to increase organizational resilience in the face of uncertainties. It is also a way to increase the sustainability of society more broadly. However, research gaps exist around the issue of whether and how MNEs and various stakeholders can effectively work together and adapt to unsystematic uncertainties. Future research can examine how organizations can draw from and coordinate their resources and capabilities in different geographic locations to effectively prepare for and respond to natural disasters.

On the one hand, if the disaster in question constitutes a global crisis, such as climate change and/or the COVID-19 pandemic, collaboration could be relatively more plausible since the threat is shared. Yet, up until now, even for these threats, countries have been reluctant to work together for the common good. On the other hand, for localized, at times catastrophic disasters, organizations and stakeholders may find a way to survive in a global crisis, and they could act in their own selfinterest. Thus, collaborations across organizations and stakeholders would be more difficult. Future research could examine characteristics of disasters and stakeholders that help or hurt collaborations.

\section{Research on Supply Chain Management}

Natural disasters also provide both challenges and opportunities for MNEs. If affected locations provide unique CSAs, MNEs with strong disaster management and preparedness capabilities may be able to recombine their internal resources with location-bound FSAs such as connecting with reliable local supply chain partners. If similar levels of CSAs can be deployed in other locations, it may be easier for MNEs to build alternative supply chains. To build a reliable alternative supply chain, MNEs should have non-location-bound FSAs such as strategic flexibility and efficient coordination and control mechanisms over partners in the chain. For these reasons, more research is needed to increase our understanding of how the reliability and flexibility of partners, and efficient coordination and control over partners in a supply chain, may positively affect the performance of an MNE facing the threat of a natural disaster. 


\section{Geographic decoupling of supply chains}

MNEs need various input factors from their subsidiaries and upstream supply chain partners across countries. Yet, natural disasters can interrupt various upstream activities including sourcing, logistics, and production. Given that, MNEs may need to recombine and economize on location-bound and non-location-bound FSAs of their subsidiaries and partners. In addition, natural disasters also affect accessibility to downstream activities such as distribution and inventory management. Therefore, MNEs need to prepare to decouple upstream and downstream activities, not only in a way to lower distance-time costs (McCann, 2011), but also to improve their reliability, stability, and continuity. Finding alternative and reliable suppliers for relationship- and client-specific activities would be very challenging if MNEs approach them from the view of efficiency.

Consequently, MNEs may need to consider establishing their own subsidiaries to improve the stable supply of inputs when faced with unsystematic uncertainties. Yet, even when managers have experience with natural disasters and acknowledge the importance of developing both location- and non-location-bound FSAs around disaster management, bounded rationality and reliability can make it difficult for managers to coordinate a decoupled supply chain. Issues to consider when managing MNE supply chains include: (1) does the geographic decoupling of upstream and downstream activities lower the damage MNEs face from (or improve their resilience against) natural disasters? (2) do better relationships with supply chain partners improve MNEs' preparation for and management of complex natural disasters? And, (3) how do MNEs transform their efficiency-oriented supply chain management models to more reliable and stable ones that will likely generate higher costs?

\section{Globalization and deglobalization in supply chains}

Facing growing unsystematic uncertainties, managers should find an optimal balance between supply chain clustering (agglomeration economies) and geographic spread (risk diversification) on the production side. On the one hand, managers like to take near-shoring and in-market sourcing into their supply chains to avoid delays and increase responsiveness and control. This may trigger the process of deglobalization. On the other hand, natural disasters can occur in any place at any time, thus MNEs need to spread their supply chains to diversify risks and leverage the benefits of global supply chains to be competitive (Gereffi, 2020). This may accelerate the process of globalization (Contractor, 2021). A more nuanced and resilient solution facing unsystematic uncertainties could be establishing regional supply chains (Rugman et al., 2009). MNEs can organize regional headquarters (hubs) and their supply chains (spikes) in a region to increase responsiveness and control. In a case of a catastrophic emergency among regional supply partners, partners in other regions can provide supplies across regions. This requires advanced coordinating skills and flexibility of supply chains and their partners. Thus, this may keep, if not increase, the nature of regional MNEs (Rugman \& Oh, 2013; Rugman \& Verbeke, 2004). This can be a central question in the field of IB.

\section{Digitalization and resilience of supply chains}

Balancing resilience and efficiency in supply chains would require fundamental changes in supply chain design and structure. It would be a difficult task for supply chain managers who emphasized cost efficiency. Supplier selection and evaluation needs to assess the reliability and responsiveness of partners as well as their cost competitiveness (Kano $\&$ Oh, 2020). This requires the involvement from top managers who should be aware of the importance of unsystematic risks and their impact on supply chains and firm performance. Digitalization enables MNEs to track and evaluate their partners. It also enables partners to join in key strategic decisions. Digitalization likely enhances the resilience of supply chains when they face unsystematic uncertainties. Newer technology such as blockchain and analytics can help MNEs to provide more prompt and complete information to their supply chain partners (Kano \& Oh, 2020; van Hoek, 2020).

\section{CONCLUSION}

In IB, natural disaster is a relatively novel research topic and a unique context to test established theories. At the same time, it offers a platform for IB scholars to contribute to scientific understanding using inter- and multi-disciplinary approaches. Existing theories and the accumulated knowledge of IB research pose both challenges and opportunities in analyzing MNEs' management of and strategy for natural disaster threats, and catastrophic events more generally. We hope that this perspective piece can be a steppingstone for IB scholars to participate in this new area of research and a make 
positive social impact on knowledge around natural disaster management.

\section{ACKNOWLEDGEMENTS}

The authors appreciate encouraging and constructive comments from the Editor-in-Chief, Alain Verbeke, and three reviewers of the journal. We also thank to Jorge Rivera, Daniel Shapiro, and Eunsuk Hong for their helpful comments on the earlier version of the paper. The authors also thank Shuna Ho for her assistance in GIS mapping.

\section{NOTES}

${ }^{1}$ Still, the fallout from the initial earthquake is not over. Recently, Japan announced that it will release the contaminated water from the wrecked Fukushima Daiichi Nuclear Power Plant into the sea. If not thoroughly treated, this water will impact human health, fisheries, and marine life; not only in Japan but throughout the Pacific Rim and beyond (McCurry, 2021). This will likely worsen political tensions in the region, negatively impact the ability of MNEs to operate and manage international supply chains, and cause another set of cascading events; all of which were triggered by the original tsunami in 2011.

${ }^{2}$ Teece, Peteraf, and Leih (2016) classify rapid technological change as "deep" uncertainty. However, compared to the probability of natural disaster recurrence or its intensity, people know better about probability of rapid technological change.

\section{REFERENCES}

Alcacer, J., \& Herman, K. 2012. Intel: Strategic decisions in locating a new assembly and test plant (A). Harvard Business School Case 713-406, September 2012. (Revised December 2013.)

Alerts, J. \& Mysiak, J. 2016. Novel multi-sector partnerships in disaster risk management. Results of the ENHANCE project. ENHANCE Project. Brussel: European Union.

Allen, L., \& Pantzalis, C. 1996. Valuation of the operating flexibility of multinational corporations. Journal of International Business Studies, 27(4): 633-653.

Arslan, A., Golgeci, I., Zhan, Z., Al-Tabbaa, O., \& HurmelinnaLaukkanen, P. 2021. Adaptive learning in cross-sector collaboration during global emergency: Conceptual insights in the context of COVID-19 pandemic. Multinational Business Review, 29(1): 21-42.

Automotive News. 2011. Chasing chips: GM's ace in the hole. April 25. https://www.autonews.com/article/20110425/ OEM02/304259930/chasing-chips-gm-s-ace-in-the-hole. Accessed 3 March 2021.

Banholzer, S., \& Kossin, J., \& Donner, S. (2014). The impact of climate change on natural disasters. In Z. Zommers \& A. Singh
${ }^{3}$ We classify disasters into risk and uncertainty for readers who are familiar with Knight's (1921) dichotomy of risk and uncertainty. However, it is important to note that it is not crystal clear to classify an event into risk or uncertainty because of at least three reasons. First, the level of predictability is a relative term. A war (or technological change) is more predictable than an earthquake, but less predictable than exchange rate risk. Second, the predictability of a type of disaster can be changed over time. For example, drought in the Australian outback was reclassified by the government from being a natural disaster to being a manageable risk because it is something farmers can anticipate and make provision for ( $\mathrm{O}^{\prime}$ Malley, 2004). Third, the main dichotomy between risk and uncertainty is the estimation of the possibility from statistical calculation. From this dichotomy, uncertainty is not estimable or avoidable, and thus it implies that people cannot prevent or overcome uncertainty. The dichotomy also ignores the ability to analyze uncertainty from practical experience, innovation, inspiration, vision, and foresight. In this sense, our views on risk and uncertainty in this paper are closer to some relatively modern views on uncertainty by Bernstein (1996), Reddy (2006), and O'Malley (2004).

${ }^{4}$ While there is a growing literature that treats MNEs and business groups as an institutional environment, it has little direct relevance to natural disasters as unsystematic uncertainties.

${ }^{5}$ We would like to thank one of our Reviewers for this suggestion.

(Eds.). Reducing disaster: Early warning systems for climate change: 21-49. Dordrecht, Netherlands: Springer.

Barney, J. B. 1991. Firm resources and sustained competitive advantage. Journal of Management, 17(1): 99-120.

Beckman, C., \& Haunschild, P. 2002. Network learning: the effects of partners' heterogeneity of experience on corporate acquisition. Administrative Science Quarterly, 47(1): 92-124.

Belderbos, R., Tong, T. W., \& Wu, S. 2020. Portfolio configuration and foreign entry decisions: A juxtaposition of real options and risk diversification theories. Strategic Management Journal, 41(7): 1191-1209.

Berger, M., \& Adam, K. 2021. In the aftermath of German floods, fires burn in southern Europe as rains drench London. Washington Post, July 26th

Berke, P. R., \& Campanella, T. J. 2006. Planning for post-disaster resiliency. Annals of the American Academy of Political and Social Science, 604(1): 192-207.

Bernstein, P. L. 1996. Against the gods: The remarkable story of risk. Wiley.

Beugelsdijk, S., McCann, P., \& Mudambi, R. 2010. Introduction: Place, space and organization-economic geography and the 
multinational enterprise. Journal of Economic Geography, 10(4): 485-493.

Buckley, P. J., \& Casson, M. 1976. The future of the multinational enterprise. Macmillan.

Buckley, P.J., Chen, L., Clegg, L.J., \& Voss, H. 2020. The role of endogenous and exogenous risk in FDI entry choices. Journal of World Business, 55(1): 101040.

Buckley, P. J., \& Ghauri, P. N. 2004. Globalisation, economic geography and the strategy of multinational enterprise. Journal of International Business Studies, 35(2): 81-98.

Bundy, J., Vogel, R. M., \& Zachary, M. A. 2018. Organizationstakeholder fit: A dynamic theory of cooperation, compromise, and conflict between an organization and its stakeholders. Strategic Management Journal, 39(2): 476-501.

Business Wire. 2017. Walmart foundation announces $\$ 563,000$ towards Mexico earthquake relief and recovery. https://www. businesswire.com/news/home/20170920006385/en/ Walmart-Foundation-Announces-565000-towards-MexicoEarthquake-Relief-and-Recovery. Accessed 14 May 2021.

Caldwell, N. D., Roehrich, J. K., \& George, G. 2017. Social value creation and relational coordination in public-private collaborations. Journal of Management Studies, 54(6): 906-928.

Canis, B. 2011. The motor vehicle supply chain: Effects of the Japanese Earthquake and Tsunami. Congressional Research Service. May 23, 2011.

Chen, J., Chen, T. H. Y., Vertinsky, I., Yumagulova, L., \& Park, C. 2013. Public-private partnerships for the development of disaster resilient communities. Journal of Contingencies and Crisis Management, 21(3): 130-143.

CNN. 2021. Africa's most populous city is battling floods and rising sears. It may soon be unlivable, experts warn. August 1st. https://www.cnn.com/2021/08/01/africa/lagos-sinkingfloods-climate-change-intl-cmd/index.html. Accessed 3 August 2021

Contractor, F. J. (2021). The world economy will need even more globalization in the post-pandemic 2021 decade. Journal of International Business Studies, 1-16.

Courtney, H., Kirkland, J., \& Viguerie, P. 1997. Strategy under uncertainty. Harvard Business Review, 75(6): 67-79.

Cutter, S. L., Barnes, L., Berry, M., Burton, C., Evans, E., Tate, E., \& Webb, J. 2008. A place-based model for understanding community resilience to natural disasters. Global Environmental Change, 18(4): 598-606.

Dahan, N. M., Doh, J., Oetzel, J., \& Yaziji, M. 2010. CorporateNGO collaboration: Co-creating new business models for developing markets. Long Range Planning, 43(2/3): 326-342.

de Holan, P. M., \& Phillips, N. 2004. Organizational forgetting as strategy. Strategic Organization, 2(4): 423-433.

Dess, G. G., \& Beard, D. W. 1984. Dimensions of organizational task environments. Administrative Science Quarterly, 29(1): $52-73$.

Dhanaraj, C., Lyles, M. A., Steensma, H. K., \& Tihanyi, L. 2004. Managing tacit and explicit knowledge transfer in IJVs: The role of relational embeddedness and the impact on performance. Journal of International Business Studies, 35(5): 428-442.

EM-DAT. (2020). The emergency events database-Universite catholoque de Louvain (UCL)-CRED, D. Guha-Sapir. Brussels, Belgium. www.emdat.be.

Forsgren, M. 2013. Theories of the multinational firm: A multidimensional creature in the global economy. Edward Elgar.

Frederick, S., Loewenstein, G., \& O'Donoghue, T. 2002. Time discounting and time preference: A critical review. Journal of Economic Literature, 40(2): 351-401.

Fuchs, S., Birkmann, J., \& Glade, T. 2012. Vulnerability assessment in natural hazard and risk analysis: Current approaches and future challenges. Natural Hazards, 64: 1969-1975.

Gereffi, G. 2020. What does the COVID-19 pandemic teach us about global value chains? The case of medical suppliers. Journal of International Business Policy, 3(3): 287-301.
Ghemawat, P. 2007. Redefining global strategy: Crossing borders in a world where differences still matter. Harvard Business School Press.

Goerzen, A., \& Beamish, P. W. 2005. The effect of alliance network diversity on multinational enterprise performance. Strategic Management Journal, 26(4): 333-354.

Hajmohammad, S., \& Vachon, S. 2016. Mitigation, avoidance, or acceptance? Managing supplier sustainability risk. Journal of Supply Chain Management, 52(2): 48-65.

Han, Z., Lu, X., Horhager, E. I., \& Yan, J. 2017. The effects of trust in government on earthquake survivors' risk perception and preparedness in China. Natural Hazards, 86(1): 437-452.

Helpman, E., Melitz, M., \& Yeaple, S. 2004. Exports versus FDI with heterogeneous firms. American Economic Review, 94(1): 300-316.

Henderson, R., \& Weber, J. (2016). Greening Walmart: Progress and controversy. Harvard Business School Case 316-042, February. (Revised February 2017.)

Hennart, J. F. 2009. Down with MNE centric theories! Market entry and expansion as the bundling of MNE and local assets. lournal of International Business Studies, 40(9): 1432-1454.

Hillman, A. J., \& Wan, W. P. 2005. The determinants of MNE subsidiaries' political strategies: evidence of institutional duality. Journal of International Business Studies, 36(3): 322-340.

Hoskisson, R., Eden, L., Lau, C. M., \& Wright, M. 2000. Strategy in emerging economies. Academy of Management Journal, 43(3): 249-267.

Howard-Grenville, J., Buckle, S. J., Hoskins, B. J., \& George, G. 2014. Climate change and management. Academy of Management Journal, 57(3): 615-623.

Johanson, J., \& Vahlne, J.-E. 1977. The internationalization process of the firm: A model of knowledge development and increasing foreign market commitment. Journal of International Business Studies, 8(1): 23-32.

Jüttner, U., Peck, H., \& Christopher, M. 2003. Supply chain risk management: Outlining an agenda for future research. International Journal of Logistics: Research and Applications, 6(4): 197-210.

Kahn, B. 2021. Here are the 6 major regions literally on fire right now. Gizmodo. https://gizmodo.com/here-are-the-5-majorregions-literally-on-fire-right-no-1847389046\#replies. Accessed 3 August 2021.

Kano, L., \& Oh, C. H. 2020. Global value chains in the postCOVID world: Governance for reliability. Journal of Management Studies, 57(8): 1773-1777.

Kano, L., \& Verbeke, A. 2015. The three faces of bounded reliability: Alfred Chandler and the micro-foundations of management theory. California Management Review, 58(1): 97-122.

Kano, L., \& Verbeke, A. 2019. Theories of the multinational firm: A microfoundational perspective. Global Strategy Journal, 9(1): 117-147.

Kieser, A., \& Koch, U. 2008. Bounded rationality and organizational learning based on rule changes. Management Learning, 39(3): 329-347.

Knight, F. H. (1921). Risk, uncertainty, and profits. New York: Harper.

Kolk, A., \& Pinkse, J. 2008. A perspective on multinational enterprises and climate change: Learning from "an inconvenient truth"? Journal of International Business Studies, 39(8): 1359-1378.

Kostova, T., Roth, K., \& Dacin, M. T. 2008. Institutional theory in the study of multinational corporations: A critique and new directions. Academy of Management Review, 33(4): 994-1006.

Kreimer, A., Arnold, M., \& Carlin, A. 2003. Building safer cities: the future of disaster risk (No. 3). World Bank Publications.

Kunz, N., Van Wassenhove, L. N., Besiou, M., Hambye, C., \& Kovacs, G. 2017. Relevance of humanitarian logistics research: Best practices and way forward. International Journal of Operations \& Production Management, 37(11): 1585-1599. 
Lee, H. 2010. Passengers touched by Korea Air Service During Ash Flight Chaos. The Korea Times, April 26th. https://www. koreatimes.co.kr/www/nation/2019/11/113_64873.html. Accessed 21 May 2020.

Lockett, A., Thompson, S., \& Morgenstern, U. 2009. The development of the resource-based view of the firm: A critical appraisal. International Journal of Management Review, 11(1): 9-28.

MacDonald, A., Clarke, A., \& Huang, L. 2019. Multi-stakeholder partnerships for sustainability: Designing decision-making processes for partnership capacity. Journal of Business Ethics, 160: 409-426.

Mahoney, J. T., \& Pandian, J. R. 1992. The resource-based view within the conversation of strategic management. Strategic Management Journal, 13(5): 363-380.

Malhotra, N., \& Kuo, A. G. 2008. Attributing blame: The public's response to Hurricane Katrina. The Journal of Politics, 70(1): 120-135.

McCann, P. 2011. International business and economic geography: Knowledge, time and transactions costs. Journal of Economic Geography, 11(2): 309-317.

McCurry, J. (2021). Fukushima: Japan announces it will dump contaminated water into sea. The Guardian, April 13, 2021. Accessed 14 April 2021.

Meyer, K. E., \& Peng, M. W. 2016. Theoretical foundations of emerging economy business research. Journal of International Business Studies, 47(1): 3-22.

Narula, R., Asmussen, C. G., Chi, T., \& Kundu, S. K. 2019. Applying and advancing internalization theory: The multinational enterprise in the twenty-first century. Journal of International Business Studies, 50(8): 1231-1252.

Nohrstedt, D., Mazzoleni, M., Parker, C. F., \& Di Baldassarre, G. 2021. Exposure to natural hazard events unassociated with policy change for improved disaster risk reduction. Nature Communications, 12: 193.

North, D. 1990. Institutions, institutional change and economic development. Cambridge University Press.

O'Grady, S., \& Lane, H. W. 1996. The psychic distance paradox. Journal of International Business Studies, 27(2): 309-333.

Oetzel, J., \& Oh, C. H. 2014. Learning to carry the cat by the tail: Firm experience, disasters, and multinational subsidiary entry and expansion. Organization Science, 25(3): 732-756.

Oetzel, J., \& Oh, C. H. 2021. A storm is brewing: Antecedents of disaster preparation in risk-prone locations. Strategic Management Journal, 42(8): 1545-1570.

Oh, C. H., \& Oetzel, J. M. 2011. Multinationals' response to major disasters: How does subsidiary investment vary in response to the type of disaster and the quality of country governance. Strategic Management Journal, 32(6): 658-681.

Oh, C. H., \& Oetzel, J. 2017. Once bitten twice shy? Experience managing violent conflict risk and MNC subsidiary-level investment and expansion. Strategic Management Journal, 38(3): 714-731

Oh, C. H., Oetzel, J., Rivera, J., \& Lien, D. 2020. Natural disasters and MNC sub-national investments in China. Multinational Business Review, 28(2): 245-274.

Oh, C. H., \& Reuveny, R. 2010. Climatic natural disasters, political risk, and international trade. Global Environmental Change, 20(2): 243-254.

Oh, C.H., Shin, J., \& Oetzel, J. (2021). How does experience change firms' foreign investment decisions to non-market events? Journal of International Management, 27(1): 100802.

Olcott, G., \& Oliver, N. 2014. Social Capital, sensemaking, and recovery: Japanese companies and the 2011 earthquake. California Management Review, 56(2): 5-22.

O'Malley, P. 2004. Risk, uncertainty and government. The Glass House.

Pavlou, P. A., \& El Sawy, O. A. 2011. Understanding the elusive black box of dynamic capabilities. Decision Sciences, 42(1): 239-273.
Pearson, C. M., \& Mitroff, I. I. 1993. From crisis prone to crisis prepared: A framework for crisis management. Academy of Management Journal, 7(1): 48-59.

Peng, M. 2003. Institutional transitions and strategic choices. Academy of Management Review, 28(2): 275-296.

Penn, I., Eavis, P., \& Glanz, J. (2019). How PG\&E ignored fire risks in favor of profits. New York Times, March 18th. Accessed 5 May 2021.

Perrow, P. 2011. The next catastrophe: Reducing our vulnerabilities to natural, industrial, and terrorist disasters. Princeton University Press.

Pescaroli, G., \& Alexander, D. (2015). A definition of cascading disasters and cascading effects: Going beyond the "toppling dominos" metaphor. GRF Davos Planet@Risk, 3(1): 58-67.

Reddy, S. G. 2006. Claims to expert knowledge and the subversion of democracy: The triumph of risk over uncertainty. Economy and Society, 25(2): 222-254.

Rivera, J., \& Clement, V. 2019. Business adaptation to climate change: American ski resorts and warmer temperatures. Business Strategy and the Environment, 28(1): 1285-1301.

Rivera, J., Oh, C. H., Oetzel, J., \& Clement, V. 2021. Business adaptation to climate change. Cambridge University Press.

Rugman, A. M. 1976. Risk reduction by international diversification. Journal of International Business Studies, 7(2): 75-80.

Rugman, A. M., Li, J., \& Oh, C. H. 2009. Are supply chains global or regional? International Marketing Review, 26(4/5): 384-395.

Rugman, A. M., \& Oh, C. H. 2013. Why the home region matters: Location and regional multinationals. British Journal of Management, 24(4): 463-479.

Rugman, A. M., Oh, C. H., \& Lim, D. S. K. 2012. The regional and global competitiveness of multinational firms. Journal of the Academy of Marketing Science, 40(2): 218-235.

Rugman, A. M., \& Verbeke, A. 2003. Extending the theory of the multinational enterprise: Internalization and strategic management perspectives. Journal of International Business Studies, 34(2): 125-137.

Rugman, A. M., \& Verbeke, A. 2004. A perspective on regional and global strategies of multinational enterprises. Journal of International Business Studies, 35(1): 3-18.

Rugman, A. M. \& Verbeke, A. (2008). Internalization theory and its impact on the field of international business. In J.J. Boddewyn (Ed.), International business scholarship: AIB fellows on the first 50 years and beyond: 155-174. Emerald.

Sanchez, R. 1995. Strategic flexibility in product competition. Strategic Management Journal, 16(S1): 135-159.

Shapiro, D., Hobdari, B., \& Oh, C. H. 2018. Natural resources, multinational enterprises and sustainable development. Journal of World Business, 53(1): 1-14.

Shaver, M. J., \& Flyer, F. 2000. Agglomeration economies, firm heterogeneity, and foreign direct investment in the United States. Strategic Management Journal, 21(12): 1175-1193.

Sheffi, Y. 2015. The Power of resilience: How the best companies manage the unexpected. The MIT Press.

Skoufias, E. 2003. Economic crises and natural disasters: Coping strategies and policy implications. World Development, 31(7): 1087-1102.

Slovic, P. (Ed.). 2000. Perception of risk. Earthscan Publications Ltd.

Smith, C. 2015. Radiation form Fukushima disaster still affects 32 million Japanese. Our World, United Nations University. https://ourworld.unu.edu/en/radiation-from-fukushimadisaster-still-affects-32-million-japanese. Accessed 12 April 2021.

Sobel, R. S., \& Leeson, P. T. 2007. The use of knowledge in natural-disaster relief management. The Independent Review, 11(4): 519-532.

Sullivan, D. P., \& Daniels, J. D. 2008. Innovation in international business research: A call for multiple paradigms. Journal of International Business Studies, 39(6): 1081-1090. 
Tajitsu, N. Five years after Japan quake, rewiring of auto supply chain hits limits. March 30, 2016. Reuters. Accessed 14 April 2021.

Tashman, P., \& Rivera, J. 2016. Ecological uncertainty, adaptation, and mitigation in the US Ski Resort Industry. Strategic Management Journal, 37(7): 1507-1525.

Taylor, D.B. 2021. Canadian province declares a state of emergency, evacuating thousands. New York Times. July 21st. https://www.nytimes.com/2021/07/21/world/canada/ british-columbia-wildfires.html. Accessed 8 August 2021.

Teece, D., Peteraf, M., \& Leih, S. 2016. Dynamic capabilities and organizational agility: Risk, uncertainty, and strategy in the innovation economy. California Management Review, 58(4): 13-35.

Teece, D., Pisano, G., \& Shuen, A. 1997. Dynamic capabilities and strategic management. Strategic Management Journal, 18(7): 509-533.

Teegen, H., Doh, J. P., \& Vachani, S. 2004. The importance of nongovernmental organizations (NGOs) in global governance and value creation: An international business research agenda. Journal of International Business Studies, 35(6): 463-483.

Tesselaar, M., Botzen, W. J., Haer, T., Hudson, P., Tiggeloven, T., \& Aerts, J. C. 2020. Regional inequalities in flood insurance affordability and uptake under climate change. Sustainability, 12(20): 8734.

Tharoor, I. The climate news is about to get a lot worse. Washington Post, August 6th, 2021. https://www. washingtonpost.com/world/2021/08/06/climate-news-unipcc/. Accessed 10 August 2021.

Tierney, K. J., Lindell, M. K., \& Perry, R. W. 2001. Facing the unexpected: Disaster preparedness and response in the United States. Joseph Henry Press.

Tihanyi, L., Devinney, T.M., \& Pedersen, T. 2012. Introduction to part II: Institutional theory in international business and management. In L. Tihanyi, T. Devinney, \& T. Pedersen (Eds.) Institutional theory in international business and management: 33-42. Emerald Group Publishing Limited.

Tilcsik, A., \& Marquis, C. 2013. Punctuated generosity: How mega-events and natural disasters affect corporate philanthropy in US communities. Administrative Science Quarterly, 58(1): 111-148.

United States Chamber of Commerce Foundation (USCCF). (2019). 8th annual building resilience through private-public partnerships conference. July 23-24, 2019, Washington, D.C.

Vakil, B. \& Linton, T. (2021). Why we're in the midst of a global semiconductor shortage. Harvard Business Review Online. February 26.

Vakis, R. N. (2006). Complementing natural disasters management: The role of social protection. World Bank, Social Protection.

Van Hoek, R. I. 2020. Research opportunities for a more resilient post-COVID-19 supply chain-closing the gap between research findings and industry practice. International Journal of Operations \& Production Management, 40(4): 341-355.

van Hoorn, A., \& Maseland, R. 2016. How institutions matter for international business: Institutional distance effects vs institutional profile effects. Journal of International Business Studies, 47(3): 374-381.

Van Tulder, R., Rodriques, S. B., Mirza, H., \& Sexsmith, K. 2021. The UN's sustainable development goals: Can multinational enterprises lead the Decade of Action? Journal of International Business Policy, 4(1): 1-21.

Verbeke, A. 2003. The evolutionary view of the MNE and the future of internalization theory. Journal of International Business Studies, 34(6): 498-504.
Verbeke, A., \& Greidanus, N. 2009. The end of the opportunism vs trust debate: Bounded reliability as a new envelope concept in research on MNE governance. Journal of International Business Studies, 40(9): 1471-1495.

Verbeke, A., \& Yuan, W. 2005. Subsidiary autonomous activities in multinational enterprises: A transaction cost perspective. Management International Review, 45(2): 31-52.

Visser, H., Petersen, A. C., \& Ligtvoet, W. 2014. On the relation between weather-related disaster impacts, vulnerability and climate change. Climatic Change, 125(3): 461-477.

Walsh, J. P., \& Ungson, G. R. 1991. Organizational memory. Academy of Management Review, 16: 57-91.

Waugh, W. L., \& Streib, G. 2006. Collaboration and leadership for effective emergency management. Public Administration Review, 66(s1): 131-140.

Webb, G. R., Tierney, K. J., \& Dahlhamer, J. M. 2000. Businesses and natural disasters: Empirical patterns and unanswered questions. Natural Hazards Review, 1(2): 83-90.

Westney, E. (1993). Institutionalization theory and the MNE. In S. Ghoshal and E. Westney (Eds.), Organization theory and the multinational corporation: 53--76. St Martin's Press.

Wijkman, A., \& Timberlake, L. 1984. Natural disasters. Acts of God or acts of man? Earthscan.

Williams, T. A., \& Shepard, D. A. 2016. Building resilience or providing sustenance: Different paths of emergent ventures in the aftermath of the Haiti Earthquake. Academy of Management Journal, 59(6): 2069-2102.

Wolf, J., Dunemann, T., \& Egelhoff, W. G. 2012. Why MNCs tend to concentrate their activities in their home region. Multinational Business Review, 20(1): 67-91.

Woods, M. 2009. A contingency theory perspective on the risk management control system within Birmingham City Council. Management Accounting Research, 20(1): 69-81.

Yamori, K., \& Goltz, J. 2021. Disasters without borders: The coronavirus pandemic, global climate change and the ascendancy of gradual onset disasters. International Journal of Environmental Research and Public Health, 18(6): 3299.

Zaheer, S. 1995. Overcoming the liability of foreignness. Academy of Management Journal, 38(2): 341-363.

Zhang, Y., Lindell, M. K., \& Prater, C. S. 2009. Vulnerability of community business to environmental disasters. Disasters, 33(1): 38-57.

\section{ABOUT THE AUTHORS}

Chang Hoon Oh is the William \& Judy Docking Professor of Strategy in the School of Business, University of Kansas. His research interests include non-market strategy, business continuity and sustainability, and globalization versus regionalization. He has extensively studied multinational strategies for managing and valuing various nonmarket risks such as natural disasters, technological disasters, political conflicts, and social conflicts.

Jennifer Oetzel is Professor of Strategy and Kogod IB Professor in the Management Department at American University in Washington, D.C. Her 
research focuses on the competitive implications of social, economic, and environmental sustainability challenges. She also studies business response to climate change, particularly natural disasters, and the management of business risk in conflict-affected countries.

Publisher's Note Springer Nature remains neutral with regard to jurisdictional claims in published maps and institutional affiliations.

Accepted by Alain Verbeke, Editor-in-Chief, 7 September 2021. This article has been with the authors for two revisions. 